\title{
On-line health companion contact among chronically ill in the Netherlands
}

\author{
Adrie C. M. Dumaij • E. C. G. Tijssen
}

Received: 12 November 2010 / Accepted: 9 March 2011 / Published online: 30 March 2011

(C) The Author(s) 2011. This article is published with open access at Springerlink.com

\begin{abstract}
A health companion is a patient who supports another patient or patient group with a similar health condition. Health companions deliver more and more support by the Internet. However, little is known about the characteristics of the users, their motivation, type of technology used and effects on health and the healthcare delivery process. The objective of the paper is to understand motivation, technology and effects of on-line health companion contact in the Netherlands concerning chronic diseases (DBM, COPD, CHF, CRD, CMD). The On-line Health Companion Contact Model was created to frame the research process. An extensive on-line questionnaire was taken from patients with various chronic disorders and using on-line health companion contact to obtain quantitative and qualitative data. Obtaining information was found the key motivation for applying on-line health companion contact and several characteristics play a role in the selection to use a specific website, including: closed access; the topics discussed; the easy use; the type of users and a clear structure. Respondents prefer website facilitated by a forum or social networking site. Other factors are the possibility to share experiences with other patients, to find recognition and understanding and to meet new people. These positive aspects are of greater importance than the perceived barriers including privacy concerns, negative stories and whining other users and concerns regarding the
\end{abstract}

\footnotetext{
A. C. M. Dumaij $(\bowtie)$

Sector for Public Sector Efficiency (IPSE) Studies,

Delft University of Technology,

Delft, the Netherlands

e-mail: a.c.m.dumaij@tudelft.nl

E. C. G. Tijssen

VU University, Faculty Earth and Life Science,

Amsterdam, the Netherlands
}

quality of information. On-line health companion contact can increase the quality of life and self-management because respondents perceived to be better informed, better able to accept their disease, better deal with their situation and to receive an increased amount of social support.

Keywords Health companion · Self management · Patient empowerment . Internet

\section{Introduction}

\subsection{Background}

The Dutch healthcare system experiences tensions because of increasing and changing demands for healthcare services. Demographic changes will have serious impact on the healthcare sector from 2015 to 2025 and become imperative from 2025 to 2050 [1]. The life expectancy increases and more people reach high age. Also, the number of persons with a chronic disease is expected to increase in the next twenty years. The largest increase is expected in the number of persons with diabetes and osteoporosis [2]. In addition, an alarming trend can be observed at the supply side of healthcare as relatively less juvenile are available for a job in this sector leading to an even larger shortage of healthcare personnel in the near future. Last but not least, tight budgetary constraints and increasing demand for high quality increase the tension on the healthcare sector even more [3].

The increasing production gap is of great concern to policy makers [4]. Therefore, the Ministry of Health invests in innovations in healthcare to limit problems on the labor market. Government policy is to provide healthcare services to chronically ill close to their houses. The current 
vision is that people have to take more responsibility in the prevention and treatment of disease. This phenomenon is called self-responsibility. The question is how to empower patients in order to pick up this responsibility. To reach that, they need more health information, specific information concerning their own health condition and tools to support their daily activities at home, a coach or support from others who can help them or give advices [5]. This form of support may come from health companions: persons in similar situations with similar impairment. With the rise of social media health companions no longer have to meet physically but exchange ideas via the Internet. So, on-line health companion contact refers to contact between people with similar health problems which support each other on the Internet [6]. Other terms used are on-line support group, virtual contact group or community, self help group, Egroup and peer-to-peer on-line support group. This study focuses on on-line health companion contact among chronically ill.

\subsection{Previous research}

Patients seek (on-line) health companion for contact emotional processing, social contacts and knowledge exchange for coping with their disease ([7-19]). Aspects that played a role included: find and share information; share experiences; share advices; increase self-confidence; better accept health complaints and deal with them; acquire the sympathy and empathy of health companions; find social support; develop a (new) social identity; experience the feeling of togetherness and common purpose; and advocacy.

A great variety of Dutch on-line health companion contact services exist depending on their purposes, type of users, size, structure and form. Patients often prefer on-line health companion contact above participation in face-toface groups because of advantages such as independence of time, place and reasonable costs. Participants can reach a wider range of other patients and thereby gain access to even more information [17] and support for coping [20]. Cummings et al. [21] found that people who receive little social support are active participants in on-line health companion contact. Participants have the possibility to communicate anonymously, which allows for discussing sensitive or controversial topics. People find emotional support and get the opportunity to share their stories and concerns with other patients [14]. This empathic or affective type of support is characterized by comforting and encouraging, or at least showing sympathy and understanding of what others experience. Of particular importance is the 'recognition' experienced by on-line health companions. Little is known about the effects on health conditions, however, weak evidence was found that on-line health companion contact contributed to reducing healthcare consumption ([14, 17]). Several studies focus on the 'service side' of on-line patient support groups and report how often certain on-line health companion groups were visited and how often people sent postings to these groups during a certain period ([22, 23]).

Patient empowerment refers to the new, proactive role of patients concerning their own health and care, a phenomenon that developed rapidly with the computerization of the society [17]. The potential to empower patients through on-line health companion networks is subject of debate $([18,24,25])$. There is a lack of empirical evidence of the effects of using on-line support groups on patient empowerment ([26, 27]). A first study by [28] suggests that participation in on-line health companion contact can contribute to the patient empowerment.

Very few studies reveal disadvantages like limited access for the illiterate and persons with other communication disabilities, lack of non-verbal cues, undetermined quality and reliability of information, the confrontation with negative aspects of the disease in the (near) future, and even the delay of seeking professional help. Physicians who acted as an editor of on-line forums found that information exchanged by patients was often conventional and not harmful to health companions ([29, 30]). Cotten and Gupta [31] and Uden-Kraan [29, 32] found that persons using the Internet regarding health and disease are young, with high education level and having a job, so a natural exclusion exists of other persons. However, a recent study conducted among 1,700 Dutch people above 45 years of age showed that this group is completely familiar with computer usage and the on-line environment [33]. They use the computer at work and/or for leisure. The most frequently used applications are e-mail and surfing the Internet, but also word processing, Internet banking and Facebook are used by the majority of respondents. comScore [34] showed that Twitter is also an attractive tool used by Dutch persons with age between 45 and 54 and that the majority of the 10 million worldwide Twitter users is 35 years or older.

Finally, since in some cases there are no formalized guidelines or professional moderators for websites, the exchange within the group might include negative, aggressive and socially inappropriate remarks [35]. Obviously, design criteria for the on-line application must comply to the appropriate computer-mediated communication standards [19] and security standards [36].

\subsection{Research objective}

The objective of this research is to characterize users of online health companion contact, to delineate their motivation 
and to find effects on self-management. The focus is on the Dutch population with high incidence chronic diseases [37], i.e.: chronic heart failure (CHF), diabetes (DBM), asthma or Chronic Obstructive Pulmonary Disease (COPD), rheumatic diseases (RD), chronic renal disease (CRD) and chronic muscle disorders (CMD). What motivates people with these chronic diseases to use health companion contact and to what extent does this increase self-management?

To answer this key question, further research questions are derived:

1. To what degree is on-line health companion contact used by people with chronic disease explained by predisposing factors,

2. enabling factors, and

3. need for care factors?

4. How is on-line health companion used?

5. What is the effect on health outcome?

6. What is the effect on self-management?

\section{Method}

First, a literature and desk study was applied to frame user and context characteristics, and to identify available tools for on-line health companion contact. Second, an on-line questionnaire was taken from on-line health companions in order to rate the characteristics and technology qualitatively and quantitatively. Finally, the results were analyzed and discussed.

\subsection{On-line health companion contact model}

The literature study was conducted to find relevant background information and a suitable model to describe factors affecting the choices of patients to use health companion contact services on the Internet. The on-line search engine Google and Pubmed database were visited. Table 1 shows search terms and synonyms used in various combinations. This yielded several hundreds of articles related to health behavior, health information seeking on the Internet and on-line health companion contact. Meaningful papers were selection based on the keywords and after reading the abstracts.

To analyze and explain the factors which affect health behavior and Internet use for health related purposes among chronically ill, models and frameworks on patient decision making were drawn from literature. We derived the On-line Health Companion Contact (OHCC) Model shown in Fig. 1, from the Chronic Care Model and the Complementary and Alternative Medicine (CAM) Healthcare Model. The OHCC Model provides an overview of the different factors found in literature that influence the motivations of patients for using on-line health companion contact. It consists of different steps; the first three steps refer to factors describing the characteristics of users. The fourth step 'on-line health companion use' describes the content, manner and purpose of use. The last step refers to the outcomes of care, identifying the effects on health and self management.

An explorative desk study was performed to understand different types of health communication technologies and on-line health companion contact available. Again, on-line search engine Google and the Pubmed database were consulted by using key terms as presented in Table 1. An overview of on-line health companion contacts organized around the chronic disorders DBM, CHF, CRD, rheumatic diseases, asthma or COPD and chronic muscle disorders is shown in Table 2.

Finally, operational on-line health companion contacts were collected, again by feeding the key terms into the Google search engine and restricting to Dutch sites. Four selection criteria were added:

- The website has to be used actively (everyday messages are posted);

- The number of registered users has to be large (more than 100 registered users);

- The website provides space for posting items for research purposes;

- Access is open for everyone to read messages (to react registration might be needed).

In total, 28 different websites matched these criteria. Six were organized around DBM, four around CHF, three around CRD, eight around rheumatic disorders, five around Asthma/COPD and two around chronic muscle disorders. The websites for rheumatic patients included both, forums focused on rheumatic disorders in general and two forums for people with specific chronic rheumatic disorders. All websites could be accessed free of charge. The majority of websites allowed everyone to read messages. For posting messages, stories or reactions registration was required from the webmaster. The results are shown in Table 2.

The administrators or webmasters of these on-line tools were contracted via email, and asked for permission to post la link to the on-line questionnaire. Twenty four out of 28 webmasters provided permission, five did not respond, not even after reminder emails. The websites included in this study are summarized in Table 4. The calls to include respondents were made specific for each website. The on-line questionnaires could be completed during 25 days (March19 to April 12, 2010).

\subsection{The on-line questionnaire}

The concepts included in the OHCC Model were validated against a sample of actual participants of on-line health 
Table 1 Key terms used to find suitable literature

\begin{tabular}{|c|c|}
\hline Topic/theme & Terms and synonyms used in various combinations \\
\hline Background information & $\begin{array}{l}\text { health companion contact (Dutch: lotgenotencontact), social support on Internet, } \\
\text { successful on-line health companion contact, advantages and disadvantages of } \\
\text { on-line health companion contact, chronically ill, health related Internet usage, } \\
\text { on-line health information seeking, peer support. }\end{array}$ \\
\hline Conceptual framework. & $\begin{array}{l}\text { health behaviour models (Health Belief Model and CAM (Complementary and } \\
\text { Alternative Medicine therapies) Healthcare Model), Chronic Care Model, } \\
\text { predictors of using on-line health companion contact, determinants of using } \\
\text { Internet for health information. }\end{array}$ \\
\hline Health communication technologies. & $\begin{array}{l}\text { Web } 2.0 \text {, social media, Internet communication technologies, Health } 2.0 \text {, health } \\
\text { information on the Internet, on-line health information seeking. }\end{array}$ \\
\hline $\begin{array}{l}\text { Health companion contact specific for DBM, CHF, CDK, asthma/ } \\
\text { COPD, rheumatic disorders, chronic muscle disorders. }\end{array}$ & $\begin{array}{l}\text { Different types of technological tools (forum, blog, Hyves, mailing lists etc.) in } \\
\text { combination with on-line health companion contact for the specific diseases on } \\
\text { which this study focused. }\end{array}$ \\
\hline
\end{tabular}

Hyves is the largest social networking site in the Netherlands and is similar to MySpace and Facebook. Hyves was established in 2004. In January 2011 there were over 10,9 million accounts, mostly by Dutch inhabitants

companion contact. A questionnaire was chosen over conducting interviews because the tool of interest is an on-line service and it is assumed that the best results will be obtained when assessing this by the same medium. In addition, on-line questionnaires are efficient. The questionnaire was designed using the on-line tool SurveyMonkey.com.

The questions were developed based on the conceptual framework, the background information and the relationship between them. Theoretical concepts were chosen according to the OHCC Model. Questionnaire items were grouped into themes, for example personal characteristics, ordered on the assumption that it would be easier for the patient to start filling out questions about general characteristics and experiences, before asking specific information about their perspectives, motivation and purposes. A pilot version was trialed for intelligibility and usability with 12 public health researchers and interested colleagues. After that, a few modifications were applied with respect to phrasing questions and the number of questions.

The on-line questionnaire mainly consisted of closed items, which were among others based on parts of validated questionnaires. Some concepts of the OHCC Model were not covered by the closed items. A few open items focused on collecting new and in-depth information concerning motivation. The questionnaire was developed so that it could be completed within a maximum of $15 \mathrm{~min}$. Furthermore, it was created in Dutch, the respondents' native language. The measures included in this study are summarized in Table 3, with open-ended items within brackets. The complete questionnaire can be found in [38].

In total 353 users clicked on the hyperlink to fill out the questionnaire. Obviously, a response rate is not available due to the fact that it is not known how many participants of the on-line groups under study red the calls. From the people who clicked on the hyperlink, 195 (55\%) filled out the questionnaire completely as seen in Table 4.

\subsection{Analysis of results}

The analysis of the quantitative and qualitative data obtained from the on-line questionnaire and literature
Fig. 1 On-line Health Companion Contact Model

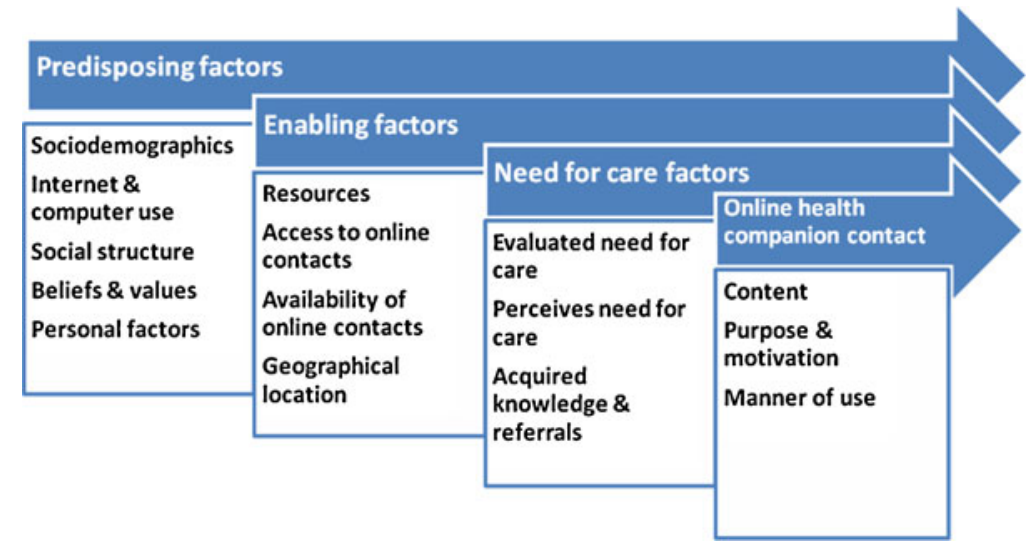

Outcome of Care

Improved QoL

Increased selfmanagement 
Table 2 On-line health companion contact tools organized around various chronic diseases

Disease Characteristics Website

On-line forums

Diabetes

CHF

CRD

Rheumatic diseases

Asthma/COPD

Chronic muscle

disorders

Various chronic diseases

Social networking websites

Diabetes

CHF

CRD
Organized by DVN, maintained by volunteers; Large number of registered users, actively used forum.

Organized by vragenoverdiabetes.nl; Registration is not needed (open access).

Overview of different on-line forums about DBM; Large number of registered users, actively used forum.

Website providing news and information related to DBM and forum to discuss with other patients; Registration is needed to post messages.

Forum for young and old people with DBM; Small number of members.

Organized by voorkomhartaanval.nl; Open access for everyone

Organized for and created by people with cardiac or vascular disease; Registration is needed to post messages.

Organized by hartgenoten.nl; Large number of registered users, actively used forum.

Organized by NVN; Large number of registered users, actively used forum.

Provides exchange of information and experiences with health companions; Not that actively used.

Discussion of various topics related to rheumatism; Large number of registered users, actively used forum.

Organized by startpagina.nl; Large number of registered users, actively used forum.

On-line health companion contact for LE patients; Actively used forum, registration is acquired.

Forum organized around Bechterew's diseases; Large number of registered users, actively used forum.

Organized by Astma Fonds for Asthma and COPD; Large number of registered users, actively used forum.

Discussion of various topics related to COPD; Large number of registered users, actively used forum.

Forum for Asthma and COPD patients; Organized by startpagina. $\mathrm{nl}$; Large number of registered users, actively used forum.

Discussion of various topics related to COPD and Asthma; Registration is needed to post messages; Not that actively used.

Organized by VSN; Large number of users, actively used forum. To read and post messages no registration is needed, however a closed forum is available as well.

Medical forums about various health problems; Intermediary between patients and care providers; Closed access to private area of this website.

Focused on people suffering from pain and fatigue due to chronic illnesses. Registration is needed.

Everyone who has a profile on Hyves can become a member of this social network; Large number of members and actively used.

Everyone who has a profile on Hyves can become a member of this social network; Large number of members and actively used.

Organized by Dutch Diabetes Foundation; Everyone who has a profile on Hyves can become a member of this social network; Large number of members and actively used.

Created by dLife, offering information and community support for type 1 and 2 DBM; Group is open to everyone.

Social network organized for heart failure patients; Everyone who has a profile on Hyves can become a member of this social network.

Social network organized for people with kidney problems. Also active on Facebook and Twitter; Everyone who has a profile on Hyves can become a member of this social network; Large number of members and actively used.

Organized for people involved in kidney transplants; Only accessible for members; Large number of members and actively used. diabetesforum.nl

vragenoverdiabetes.nl/lotgenoten

diabetesforums.nl

www.diabetesweb.nl

www.diabetesbijjongenoud.nl/forum

voorkomhartaanval.nl/lotgenoten

hartenvaatforum.nl

hartgenoten.nl/forum

forum.nvn.nl

nierdialyse.nl/lotgenoten

reumaforum.nl

reuma.startpagina.nl/prikbord

lupuspatientengroep.n1/forum

bechterewforum.nl

longforum.nl

COPDLongemfyseem forum.nl

copd.startpagina.nl/prikbord

www.astma-copd.nl/lotgenoten

www.vsn.nl/myocafe

dokter.nl

www.chronischeziektemetmoeheidenpijn.nl/forum

diabetes.hyves.nl

diabetesclub1.hyves.nl

diabetesfonds.hyves.nl

LinkedIn: dLife group

hartfalen.hyves.nl

nierpatiënten.hyves.nl

zwannie1968.hyves.nl 
Table 2 (continued)

\begin{tabular}{|c|c|c|}
\hline Disease & Characteristics & Website \\
\hline \multirow[t]{4}{*}{ Rheumatic diseases } & $\begin{array}{l}\text { Organized by Reumapatiëntenbond; Large number of } \\
\text { members and actively used. }\end{array}$ & reumalijn.hyves.nl \\
\hline & $\begin{array}{l}\text { Large number of members and actively used; Accessible } \\
\text { for everyone. }\end{array}$ & reumaenik.hyves.nl \\
\hline & $\begin{array}{l}\text { Meeting place for people who have to deal with rheumatic } \\
\text { diseases. Accessible for everyone. }\end{array}$ & reuma-on-line.hyves.nl \\
\hline & Hyves pages for LE patients; Closed access. & lupuserythemathodes.hyves.nl \\
\hline \multirow[t]{2}{*}{ Asthma/COPD } & $\begin{array}{l}\text { For everyone with asthma; Large number of members and } \\
\text { actively used; Everyone who has a profile on Hyves can } \\
\text { become a member of this social network. }\end{array}$ & astma.hyves.nl \\
\hline & $\begin{array}{l}\text { Large social network for people with COPD; Everyone can } \\
\text { become a member. }\end{array}$ & COPD longemfyseem Hyves \\
\hline $\begin{array}{l}\text { Chronic muscle } \\
\text { disorders }\end{array}$ & $\begin{array}{l}\text { Social network for people concerned with muscle disorders; } \\
\text { Everyone can become a member. }\end{array}$ & spierziekte.hyves.nl \\
\hline \multicolumn{3}{|c|}{ 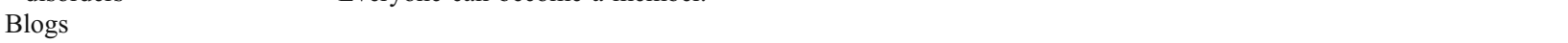 } \\
\hline $\mathrm{CHF}$ & $\begin{array}{l}\text { Organized by hartgenoten.nl; Registration is needed to post } \\
\text { messages or stories. }\end{array}$ & hartgenoten.nl/hartverhalen \\
\hline CRD & Blog focused on partners of kidney patients. & mijneigenkoers.nl/partner \\
\hline Asthma/COPD & $\begin{array}{l}\text { This website provides news, stories and a forum related to } \\
\text { asthma and COPD. }\end{array}$ & www.astmacopdnieuws.nl \\
\hline Various chronic diseases & $\begin{array}{l}\text { To read and post short messages; Organized by blog.nl; } \\
\text { Open access for everyone. }\end{array}$ & Blog.nl, for example dieet.blog.nl/diabetes \\
\hline \multicolumn{3}{|l|}{ Mailing list } \\
\hline Diabetes & $\begin{array}{l}\text { Exchange information; Organized by Yahoo! Health Groups; } \\
\text { To use the list a yahoo account is needed. }\end{array}$ & $\begin{array}{l}\text { health.groups.yahoo.com/group/ } \\
\text { Diabetesmailinglijst }\end{array}$ \\
\hline \multicolumn{3}{|l|}{ On-line communities } \\
\hline \multirow[t]{3}{*}{ Diabetes } & On-line meeting place focused on children/youth. & www.cyberpoli.nl \\
\hline & Dutch diabetes community; Users have to register and sign in. & www.diabee.nl \\
\hline & $\begin{array}{l}\text { On-line meeting place including information, discussion } \\
\text { forum and space to post personal stories. }\end{array}$ & www.diabetenweten.nl \\
\hline Rheumatic diseases & $\begin{array}{l}\text { Community for youth with rheumatic diseases; Provides access } \\
\text { to chat room, column and forum; Users have to register } \\
\text { and sign in. }\end{array}$ & www.youth-r-well.com \\
\hline Asthma/COPD & $\begin{array}{l}\text { Website of the patient organization LMCB. Provides on-line } \\
\text { health companion contact via forum; Also active on Twitter, } \\
\text { Hyves and You Tube. }\end{array}$ & www.lcmb.nl \\
\hline
\end{tabular}

research lead to results with a descriptive and explorative character. The opinions of the patients about using on-line contact and to what extent it increases their selfmanagement have been studied. A structural analysis was applied to evaluate the responses. Similar answers are grouped together and when at least 5 respondents propose a comparable answer the group is labeled and presented in tables. Percentages of various closed responses options are also presented in tables. Patterns of users of on-line health companion contact are described.

\section{Results}

\subsection{Characteristics of respondents}

Sociodemographics Respondents are likely to be female, married and Dutch (Table 5). The mean age is $44.3(S D=$
$12.2)$ with the youngest respondent being 19 years of age and the oldest 69. Most of the respondents are aged between 41 and 60 years old. A wide range in educational level is found: $6.2 \%$ attended university, a great part conducted high vocational education and secondary vocational education and two people did not receive education beyond primary school. It appeared that a great part of the respondents (59\%) have a net income less than $€ 1,400$. This is low compared to the net monthly middle income in Netherlands, which is $€ 1,494$ [39]. However, $19.0 \%$ of the respondents did not want to provide information about their income. In total, $29.3 \%$ of the respondents have a paid job, most of them for more than $20 \mathrm{~h}$. In total $30.2 \%$ of the respondents receive social benefits either because they are not able to have a job or rejected to work because of health problems. Also some respondents who selected the response option 'other' reported that to receive Wajong, which is a payment for young disabled [40]. If people suffer 
Table 3 Measures included in on-line questionnaire

\begin{tabular}{|c|c|}
\hline Variable & Concepts \\
\hline Sociodemographics & $\begin{array}{l}\text { Gender; Age; Nationality; Marital status; Educational level; Net income per month; } \\
\text { Occupational status; Postal code (open-ended question). }\end{array}$ \\
\hline Internet and computer usage & $\begin{array}{l}\text { Computer use at home; Computer use at work; Internet connection at home; Internet usage for } \\
\text { non-email related purposes; Time spent Internet (open-ended question). }\end{array}$ \\
\hline Social structure & $\begin{array}{l}\text { Social support in daily life: Number of people living together; Possibility to discuss about health } \\
\text { problems and ask questions to family, friends and people in the neighbourhood. }\end{array}$ \\
\hline $\begin{array}{l}\text { Introduction to on-line health } \\
\text { companion contact }\end{array}$ & $\begin{array}{l}\text { Becoming familiar with the possibility to use this; Already know a user of on-line health companion } \\
\text { contact; Becoming known with the specific website currently used by the respondents. }\end{array}$ \\
\hline Beliefs and values & Risks perceived in advance of using on-line health companion contact (open-ended question). \\
\hline Benefits & $\begin{array}{l}\text { Agreement on importance of eight statements concerning benefits ( } 5 \text { point Likert scale); Additional } \\
\text { benefits perceived by respondents (open-ended question). }\end{array}$ \\
\hline Barriers & $\begin{array}{l}\text { Hesitations in advance of using on-line health companion contact (open-ended question); Degree of } \\
\text { annoyance of eight statements concerning disadvantages ( } 5 \text { point Likert scale); Additional } \\
\text { disadvantages perceived by respondents (open-ended question). }\end{array}$ \\
\hline Manner of use & Use of other healthcare services (open-ended question). \\
\hline Satisfaction with healthcare & $\begin{array}{l}\text { Satisfaction with received healthcare services; Why satisfied or not (open-ended question); Presence } \\
\text { of waiting lists for healthcare services; Reachable within } 30 \mathrm{~min} \text {. }\end{array}$ \\
\hline Personal factors & Self-care ability; Self-efficacy; Need for care control. \\
\hline Need for care factors & $\begin{array}{l}\text { Diagnosis; Self-reported health status; General happiness; Perceived need for on-line health companion } \\
\text { contact versus regular healthcare services to deal with health problems; Why (open-ended question). }\end{array}$ \\
\hline Obtained advice & $\begin{array}{l}\text { Frequency of obtaining advice related to health and disease; Frequency of referrals to healthcare } \\
\text { professionals; Frequency of following these advices. }\end{array}$ \\
\hline $\begin{array}{l}\text { Use of on-line health companion } \\
\text { contact }\end{array}$ & $\begin{array}{l}\text { Period of use; Frequency of use; Duration of use; Type of access; Technological preferences which } \\
\text { affect the selection of a specific website (open-ended question); Type of user (open-ended question). }\end{array}$ \\
\hline Purpose of use/motivation & $\begin{array}{l}\text { Agreement on frequency of ten statements about factors that gave rise to use on-line health companion } \\
\text { contact; Most important reason to start using on-line health companion (open-ended question); } \\
\text { Agreement on ten statements concerning different motives to use on-line health companion contact } \\
\text { ( } 5 \text { point Likert scale); }\end{array}$ \\
\hline Effects & $\begin{array}{l}\text { Effects of using on-line health companion contact on health (open-ended question); Agreement } \\
\text { on four statements concerning increased QoL and eleven statements concerning increased } \\
\text { self-management on a } 5 \text { point Likert scale. }\end{array}$ \\
\hline
\end{tabular}

from long term illness before their 17th birthday, they can apply for this regulation. Most respondents live in ZuidHolland. Next, most people come from Noord-Brabant and Noord-Holland. The smallest number of respondents live in Drenthe or Zeeland. This distribution of respondents over the Netherlands is comparable to the population by province; however Flevoland has the least population [41].

Internet and computer usages In general, respondents are extensive Internet and computer users. They all used a computer at home and about $35 \%$ also used a computer at work. Except one, all respondents had access to Internet at home. In addition, almost all respondents used Internet for other purposes than email. The mean time spent on the Internet was $16 \mathrm{~h}$ per week. Over $40 \%$ of the respondents reported that they typically use the Internet maximal ten hours a week.

Social structure Over $60 \%$ of the respondents lived together with two or more other people. The majority was able to talk about their health with persons close to them. Additionally, over $60 \%$ could ask questions about health to family, friends or people in their neighborhood. Respondents became familiar with the possibility to use on-line health companion contact in different ways: $33.8 \%$ learned more or less randomly about this tool while surfing the Internet and using the search engine Google for health related purposes; others got introduced to this on-line application by recommendations from others including patients $(9.2 \%)$, healthcare providers $(9.2 \%)$, family or friends $(5.6 \%)$. Further, $24.6 \%$ of the respondents selected the response option 'other.' From this group, 15 people reported that they learned about the possibility to use on-line health companion contact via Hyves and 6 people via a patient organization where they belonged to. In advance of using on-line health companion contact only $12.3 \%$ of the respondents already knew another user of this tool.

Personal factors $21.5 \%$ of the respondents need help in taking care of themselves. Except a few respondents who rarely or never $(3.6 \%)$ asked questions to their medical 
Table 4 Overview of respondents of various on-line health companion contact tools

\begin{tabular}{lll}
\hline $\begin{array}{l}\text { On-line health } \\
\text { companion contact } \\
(n=24)\end{array}$ & $\begin{array}{l}\text { Number of } \\
\text { clicks on the } \\
\text { link }(n=353)\end{array}$ & $\begin{array}{l}\text { Number of completed } \\
\text { questionnaires } \\
\text { (n 195) }\end{array}$ \\
\hline $\begin{array}{l}\text { Forums } \\
\text { Diabetesforum.nl (DVN) }\end{array}$ & 13 & 7 \\
Diabetesforums.nl & 0 & 0 \\
DiabetesWEB Forum & 1 & 0 \\
Hart\&Vaat Forum & 1 & 0 \\
Hartgenoten.nl Forum & 13 & 9 \\
ReumaForum.nl & 26 & 23 \\
Forum Lupus Patiëntengroep & 6 & 6 \\
Bechterew Forum & 16 & 11 \\
Myocafé (Forum VSN) & 23 & 16 \\
Longforum & 16 & 12 \\
(Astma Fonds) & & \\
NVN Forums & 15 & 5 \\
Reuma startpagina \\
prikbord
\end{tabular}

doctor, they sometimes $(16.9 \%)$, regular $(40.0 \%)$ or often $(39.5 \%)$ asked questions to their medical doctor. In addition, the majority $(85.1 \%)$ shared their feelings of concern about health with others. Furthermore, the high percentage $(93.8 \%)$ of respondents who indicated to have confidence in their active involvement in decisions concerning health suggests a high self-efficacy. The perceived need for care control was not that important according to the respondents because $73.3 \%$ preferred to have an equal partnership for involvement in decision about healthcare. Some respondents $(18.5 \%)$ would like to keep control in their own hands and a few $(8.2 \%)$ preferred to leave it to the doctor.
Access to conventional healthcare services In general, regular healthcare services were accessible according to the respondents: About a quarter had to deal with waiting lists and they could be reached within $30 \mathrm{~min}$ for almost $70 \%$ of the respondents.

Need for care factors As could be expected, respondents with different chronic disorders were involved in this study. Most of them (36.4\%) had a rheumatic disorder followed by Asthma/COPD (27.7\%). Less respondents with the other chronic disorders on which this study has focused were obtained. Some had multiple of these chronic disorders for example DBM and CHF. A few respondents used the on-line contact because a partner or a family member suffered from a chronic disorder. Overall, respondents were negative about their health status, however over $65 \%$ reported to be happy and $13.3 \%$ even very happy.

The characteristics of the respondents are summarized in Table 5.

\subsection{User experience, motivation and effects}

Perceived risks In total 140 respondents answered the open-ended question if other risks, than those mentioned in Table 9 (that everyone had access to my data; to become dependent on on-line contact; to receive incorrect information), were perceived in advance of using on-line health companion contact. The greatest part $(68.8 \%)$ reported that they did not perceive any risks. On the other hand, $9.3 \%$ of the respondents mentioned privacy concerns as a risk, which also appeared from the closed item: the fact that everyone had access to personal data was perceived as a risk by $35.9 \%$. Furthermore, $7.1 \%$ experienced the negative stories and the chance to feel worse because of using online contact as a risk. Five respondents mentioned that there were no risks if being careful in providing data. Finally, a few users perceived the possibility to receive wrong information or misuse of other users as a risk.

Perceived barriers The majority of respondents (84.1\%) did not have any hesitations in advance of using on-line health companion contact. 31 respondents reported that they experienced some hesitations and described them. Ten users reported to perceive negative stories of other users as a barrier which was also perceived as a risk as aforementioned. Another barrier which was reported eight times included the uncertainty if using this on-line tool was the right way to deal with health problems. Finally, privacy concerns were experienced by seven respondents as a barrier which was also mentioned as a risk. Other barriers reported only once were limited computer skills and no 
Table 5 Summary of characteristics of respondents

\begin{tabular}{|c|c|c|c|}
\hline Variable/item & Response options & Frequency $(n=195)$ & Percentage $(\%)$ \\
\hline \multicolumn{4}{|l|}{ Sociodemographics } \\
\hline \multirow[t]{2}{*}{ Gender } & Female & 166 & 85.1 \\
\hline & Male & 29 & 14.9 \\
\hline \multirow[t]{4}{*}{ Age } & $10-20$ & 5 & 2.6 \\
\hline & $21-40$ & 73 & 37.4 \\
\hline & $41-60$ & 106 & 54.5 \\
\hline & $61-70$ & 11 & 5.6 \\
\hline \multirow[t]{5}{*}{ Marital status } & Married & 103 & 52.8 \\
\hline & Single & 43 & 22.1 \\
\hline & Living together & 31 & 15.9 \\
\hline & Divorced & 13 & 6.7 \\
\hline & Widowed & 5 & 2.6 \\
\hline \multirow[t]{2}{*}{ Nationality } & Dutch & 191 & 97.9 \\
\hline & Other & 4 & 2.1 \\
\hline \multirow[t]{9}{*}{ Education level } & No education & 0 & 0 \\
\hline & Primary school & 2 & 1 \\
\hline & Low vocational education & 28 & 14.4 \\
\hline & VMBO/MAVO/MULO/ULO & 30 & 15.4 \\
\hline & Secondary vocational education & 54 & 27.7 \\
\hline & $\mathrm{HAVO} / \mathrm{MMS}$ & 10 & 5.1 \\
\hline & VWO/Gymnasium/HBS & 5 & 2.6 \\
\hline & High vocational education & 54 & 27.7 \\
\hline & University & 12 & 6.2 \\
\hline \multirow[t]{9}{*}{ Net income per month } & Less than $€ 600$ & 30 & 15.4 \\
\hline & $€ 600-€ 1,000$ & 49 & 25.1 \\
\hline & $€ 1,001-€ 1,400$ & 36 & 18.5 \\
\hline & $€ 1,401-€ 1,800$ & 18 & 9.2 \\
\hline & $€ 1,801-€ 2,200$ & 12 & 6.2 \\
\hline & $€ 2,201-€ 2,600$ & 6 & 3.1 \\
\hline & $€ 2,601-€ 3,000$ & 0 & 0.0 \\
\hline & More than $€ 3,000$ & 7 & 3.6 \\
\hline & I do not say/no idea & 37 & 19.0 \\
\hline \multirow{11}{*}{$\begin{array}{l}\text { Occupational status (multiple } \\
\text { response options were possible) }\end{array}$} & Paid job ( $\geq 20 \mathrm{~h}$ a week) & 45 & 19.1 \\
\hline & Paid job $(\leq 20 \mathrm{~h}$ a week $)$ & 24 & 10.2 \\
\hline & Responsible for keeping house & 23 & 9.8 \\
\hline & No paid job (voluntary/charity) & 16 & 6.8 \\
\hline & Student & 14 & 6.0 \\
\hline & Retired & 6 & 2.6 \\
\hline & $\begin{array}{l}\text { Not able to have a paid job due to } \\
\text { health problems (Ziektewet) }\end{array}$ & 12 & 5.1 \\
\hline & Approved (WAO/WIA) & 59 & 25.1 \\
\hline & Rehabilitation programme & 5 & 2.1 \\
\hline & Unemployed & 12 & 5.1 \\
\hline & Other... & 19 & 8.1 \\
\hline \multirow[t]{7}{*}{ Geographic region } & Zuid-Holland & 44 & 22.6 \\
\hline & Noord-Brabant & 32 & 16.4 \\
\hline & Noord-Holland & 23 & 11.8 \\
\hline & Gelderland & 19 & 9.7 \\
\hline & Overijssel & 15 & 7.7 \\
\hline & Limburg & 13 & 6.7 \\
\hline & Groningen & 11 & 5.6 \\
\hline
\end{tabular}


Table 5 (continued)

\begin{tabular}{|c|c|c|c|}
\hline Variable/item & Response options & Frequency $(n=195)$ & Percentage $(\%)$ \\
\hline & Flevoland & 9 & 4.6 \\
\hline & Utrecht & 8 & 4.1 \\
\hline & Friesland & 6 & 3.1 \\
\hline & Drenthe & 3 & 1.5 \\
\hline & Zeeland & 3 & 1.5 \\
\hline \multicolumn{4}{|l|}{ Internet and computer usage } \\
\hline Computer use at home & Yes & 195 & 100.0 \\
\hline \multirow[t]{2}{*}{ Computer use at work } & Yes & 69 & 35.4 \\
\hline & Not applicable & 93 & 47.7 \\
\hline Internet at home & Yes & 194 & 99.5 \\
\hline Non email use of Internet & Yes & 189 & 96.6 \\
\hline \multirow[t]{3}{*}{ Time spent on the Internet. } & 0-10 (hours/week) & 79 & 40.5 \\
\hline & $11-20$ & 67 & 34.3 \\
\hline & $>20$ & 48 & 24.6 \\
\hline \multicolumn{4}{|c|}{ Social structure (social support daily life; introduction to on-line health companion contact) } \\
\hline \multirow{4}{*}{$\begin{array}{l}\text { Sometimes talk with close persons } \\
\text { about health? }\end{array}$} & Rarely or never & 23 & 11.8 \\
\hline & Sometimes & 86 & 44.1 \\
\hline & Regular & 70 & 35.9 \\
\hline & Often & 16 & 8.2 \\
\hline Already know other users & Yes & 24 & 12.3 \\
\hline \multirow{6}{*}{$\begin{array}{l}\text { Learned about the possibility to use } \\
\text { on-line health companion } \\
\text { contact from... }\end{array}$} & While surfing the Internet/Google & 66 & 33.8 \\
\hline & Media & 34 & 17.4 \\
\hline & Other patients & 18 & 9.2 \\
\hline & Doctor/therapist & 18 & 9.2 \\
\hline & Family or friends & 11 & 5.6 \\
\hline & Other... & 48 & 24.6 \\
\hline \multirow{5}{*}{$\begin{array}{l}\text { I became familiar with the website } \\
\text { I use currently... }\end{array}$} & While Surfing the Internet & 92 & 47.2 \\
\hline & While searching health information & 54 & 27.7 \\
\hline & Through a known & 14 & 7.2 \\
\hline & During visit of doctor/therapist & 11 & 5.6 \\
\hline & Other... & 24 & 12.3 \\
\hline \multicolumn{4}{|c|}{ Personal factors (self-care ability; self-efficacy; need for care control) } \\
\hline Need help in taking care of yourself? & Yes & 42 & 21.5 \\
\hline $\begin{array}{l}\text { Confidence in active involvement in } \\
\text { decisions about treatment? }\end{array}$ & Yes & 183 & 93.8 \\
\hline \multirow[t]{4}{*}{ Ask questions to medical doctor? } & Rarely or never & 7 & 3.6 \\
\hline & Sometimes & 33 & 16.9 \\
\hline & Regular & 78 & 40.0 \\
\hline & Often & 77 & 39.5 \\
\hline \multirow[t]{4}{*}{ Share feelings of concern with others? } & Rarely or never & 29 & 14.9 \\
\hline & Sometimes & 78 & 40.0 \\
\hline & Regular & 68 & 34.9 \\
\hline & Often & 20 & 10.3 \\
\hline \multirow{3}{*}{$\begin{array}{l}\text { What do you prefer for involvement } \\
\text { in decisions about healthcare? }\end{array}$} & Equal partnership with doctor & 143 & 73.3 \\
\hline & Keep control in own hands & 36 & 18.5 \\
\hline & Leave it in doctor's hands & 16 & 8.2 \\
\hline \multicolumn{4}{|l|}{ Need for care factors } \\
\hline \multirow[t]{4}{*}{ Diagnosis } & Rheumatic disease & 71 & 36.4 \\
\hline & Asthma or COPD & 54 & 27.7 \\
\hline & Chronic muscle disorder & 9 & 4.6 \\
\hline & Chronic Renal Disease & 8 & 4.1 \\
\hline
\end{tabular}


Table 5 (continued)

\begin{tabular}{|c|c|c|c|}
\hline Variable/item & Response options & Frequency $(n=195)$ & Percentage $(\%)$ \\
\hline & Chronic heart failure & 7 & 3.6 \\
\hline & Diabetes & 6 & 3.1 \\
\hline & Combination of these disorders & 22 & 11.3 \\
\hline & Other chronic disorder & 12 & 6.2 \\
\hline & Parent or partner of patient & 6 & 3.1 \\
\hline \multirow[t]{4}{*}{ Well being: Perceived health status } & Poor & 55 & 28.2 \\
\hline & Fair & 116 & 59.5 \\
\hline & Good & 23 & 11.8 \\
\hline & Excellent & 1 & 0.5 \\
\hline \multirow[t]{3}{*}{ Well being: General happiness } & Not to happy & 41 & 21.0 \\
\hline & Happy & 128 & 65.6 \\
\hline & Very happy & 26 & 13.3 \\
\hline
\end{tabular}

need to meet new people. Respondents indicated how annoying they perceived the eight statements (Table 15 in [38]) regarding disadvantages which were described in literature. These statements were experienced not that annoying because the scores ranged from 2.02 (not annoying) to 3.05 (neutral). The fact that it is difficult to estimate the quality of some messages was experienced as most annoying (mean score of 3.05); the possibility that typed messages can be interpreted wrongly came in second (mean score of 3.03) and that questions were not always answered completely came in third (mean score of 2.88). The majority of respondents $(60.5 \%$, Table 6$)$ did not perceive additional disadvantages besides those mentioned in the statements as described before, which is a large number compared to the other reported disadvantages. Again the discussions which can make users feel worse were mentioned as a negative aspect of on-line health companion contact. This is an important issue because it was also mentioned as a risk and barrier. Also privacy concerns were experienced as disadvantageous which is in agreement with the perceived risks and barriers. Feelings of uncertainty were mentioned by 8 respondents which was similar to the perceived barriers.

Table 6 Most frequently mentioned disadvantages of using on-line health companion contact

\begin{tabular}{lll}
\hline $\begin{array}{l}\text { Which other disadvantages did } \\
\text { you perceive of on-line health } \\
\text { companion contact in advance } \\
\text { of using it? }\end{array}$ & $\begin{array}{l}\text { Number of similar } \\
\text { responses }(n=129)\end{array}$ & $\begin{array}{l}\text { Percentage } \\
(\%)\end{array}$ \\
\hline $\begin{array}{l}\text { No additional disadvantages to } \\
\text { closed response options }\end{array}$ & 78 & 60.5 \\
$\begin{array}{l}\text { Talk which made me feel worse/ } \\
\text { negative stories }\end{array}$ & 9 & 7.0 \\
$\begin{array}{l}\text { Privacy concerns } \\
\text { Misuse by other users/uncertainty } \\
\text { about reliability }\end{array}$ & 8 & 6.2 \\
\hline
\end{tabular}

Perceived benefits In general, respondents perceived the statements concerning advantages as important, which was in agreement with literature as described before. The most important advantage is the possibility to get into contact with others that find themselves in a similar situation quite easily (mean score of 4.11 on a 5-point scale). To be able to express themselves because of writing down their feelings and to meet people with whom they would otherwise not get into contact with were also perceived as important advantages. Feeling a sense of safety because users do not have to reveal who they are, was perceived as the least important advantage (mean score of 3.23). Additional benefits were mentioned by 135 respondents from which could be suggested that obtaining information or sharing experiences were important benefits (Table 7). Also easy (7.4\%) use and recognition (6.7\%) were

Table 7 Most frequently mentioned benefits of using on-line health companion contact

\begin{tabular}{lll}
\hline $\begin{array}{l}\text { Which other benefits did you } \\
\text { perceive of on-line health } \\
\text { companion contact in advance } \\
\text { of using it? }\end{array}$ & $\begin{array}{l}\text { Number of similar } \\
\text { responses }(n=135)\end{array}$ & Percentage (\%) \\
\hline $\begin{array}{l}\text { No other benefits than just } \\
\text { mentioned in closed question }\end{array}$ & 25 & 18.5 \\
$\begin{array}{l}\text { Obtain/exchange information } \\
\text { about disease }\end{array}$ & 21 & 15.6 \\
$\begin{array}{l}\text { Share experiences (about } \\
\text { disease and treatment) with } \\
\text { ther users }\end{array}$ & 17 & 12.6 \\
$\begin{array}{l}\text { Ease (easy way to find } \\
\text { information, from home, free) }\end{array}$ & 10 & 7.4 \\
$\begin{array}{l}\text { Recognition } \\
\text { Obtain specific information } \\
\text { from experienced experts }\end{array}$ & 8 & 6.7 \\
$\begin{array}{l}\text { Understanding } \\
\text { Contact with health } \\
\text { companions/meet } \\
\text { new people }\end{array}$ & 7 & 5.9 \\
$\begin{array}{l}\text { Place to express my } \\
\text { feelings }\end{array}$ & 6 & 5.2 \\
\hline
\end{tabular}


reported. Other advantages which were mentioned by less than five respondents included anonymity and becoming less dependent of healthcare services.

Healthcare and satisfaction In total $86 \%$ of the respondents was satisfied and $14 \%$ was unsatisfied with the healthcare services they received. A great part (19.8\%) reported to be satisfied because they received proper and effective care. Also $19.8 \%$ was satisfied because healthcare providers were listening to them and took them seriously. Furthermore, $17.4 \%$ was satisfied because the received care fitted with their needs and situation. The fact that patients could always consult their healthcare professional was also a reason to be satisfied. Finally confidence and good guidance played a role. In contrast, nine respondents were unsatisfied because they received a wrong diagnosis or information. Seven respondents mentioned that healthcare providers were not listening to them, three reported to feel approached like a number instead of a patient; that money was of greater importance than proper care or that there was a lack of solutions for health problems.

Perceived need for on-line health companion contact Respondents reported various reasons why they used on-line health companion contact or professional healthcare. For eight it was important to talk about problems and have contact with other patients. According to seven respondents, people in a similar situation were better able to understand them than medical doctors. Finally, five respondents mentioned by that it provided support and advice about how to deal with their disease. Next, 38 respondents argued that they feel more need for regular healthcare services rather than on-line health companion contact. Only medical treatment or medicines were helpful to deal with their health problems; talking with health companions did not help to make you better. It was also argued that healthcare professionals have the knowledge and expertise and therefore they were more helpful than online health companion contact. Five respondents did not need mental support, on which on-line contact has focused. The third group of respondents $(37.5 \%)$ perceived need for a combination of using regular healthcare services and online health companion contact. $15.6 \%$ experienced that regular health services were needed for the medical part and on-line health companion contact for the mental part. Others $(10.0 \%)$ mentioned that regular services focused on the theoretical part and on-line contact on the practical part, which means experiences and tips about how to deal with a disease in daily life. Also $8.8 \%$ of the respondents argued that on-line contact is complementary to regular healthcare services. Finally, six respondents reported that they become better informed and able to ask questions to their healthcare professionals.
Acquired knowledge and recommendations The majority (53.8\%, Table 9) sometimes obtained advice. Recommendations to visit healthcare professionals were obtained rarely or never by $48.2 \%$ of the respondents. From those who received advice, $57.9 \%$ was persuaded to follow this advice sometimes.

Content of use Although it was expected that mainly people who were recently diagnosed used on-line health companion contact, it appeared that people in all different stages of their illness were participating in these groups: $83.1 \%$ used this tool since a half year or longer; $32.3 \%$ already used it longer than 2 years and $7.7 \%$ visited the specific website for the first time (Table 9). Secondly, there was a wide range in the frequency of use, ranging from less than one time a month to multiple times a day, $33.3 \%$ used it multiple times a week. Also the duration of use per visit varied among users. A great part $(47.2 \%)$ used on-line health companion contact for 10 to $30 \mathrm{~min}$.

Website characteristics Respondents described various reasons why they selected the website they were using currently. The topics discussed on forums or networks were considered important by $19.5 \%$ of the respondents. From these 38 respondents, 25 used a specific website because it focused on their disease and a lot of information was provided. Also, 9.2\% mentioned the easy use as reason to select a specific tool. It was important that the website was easy accessible and comprehensible. A few users reported explicitly that Hyves was very attractive because they had already a profile on this network, therefore they could easily become a member of a group concerning their disease. Another technological issue is access; $7.7 \%$ rather use websites with closed access than open access and 4.6\% argued for the other way around. This preference for closed access was also measured with the closed item concerning access as shown in Table 9. Furthermore, the type of users played a role according to $7.7 \%$, for instance the age of members. A good example is the community for young people with rheumatic disorders, where youth can discuss their problems with each other. Four respondents indicated that they find it important to talk with people of similar ages. The organization of the website was important for $6.2 \%$ of the respondents. They visited a website as it was provided by a patient organization where they belonged to, for example the VSN, because this provided feelings of confidence. The technology used was important for 5.6\% of the respondents to select a website. Among others, the structure and lay out of a website were reported to be important. Forums which provided a clear overview were attractive to use and Hyves was experienced as an accessible technology. Furthermore, 3.1\% preferred a large number of registered users as important. Finally, 3.1\% 
argued that the fact that they were allowed to use a website whenever they want without consequences or liabilities and that they could react to messages whenever they want were important in selecting a website. In addition, respondents could report how enjoyable they experienced different technology used regarding on-line health companion contact. As seen in Fig. 2 forums were the most popular among the respondents (mean score 3.13). Also respondents were satisfied with social networking websites such as Hyves (mean score 2.59). This was comparable with openended responses about the selection of a specific website where respondents reported to prefer Hyves or forums which were structured well.

Type of user From the 44 respondents who explained their role, $47.7 \%$ reported that they read messages of others and sometimes react on these messages. Others $(25 \%)$ described that they post messages, read messages of others and start new discussions. For example one of these active users described that it was helpful for her to write down their feelings and read other stories to find recognition. Five respondents rarely or never used on-line health companion contact or just became a member and could not say what type of user they were. Finally, three users were also a moderator and performed different tasks to organize the website.

Purpose/motivation of use Respondents described various motives for using on-line health companion contact: $36.6 \%$ indicated to use this tool to obtain information related to their disease, either because they just received the diagnosis or were interested in more specific information about the disease or treatment. Obtaining information also concerned asking questions, finding answers or acquiring advice. Next, $19.4 \%$ of the respondents would like to read stories of other users to see how others deal with their disease; probably they could learn something from them. The

How enjoyable were different technologies experienced?

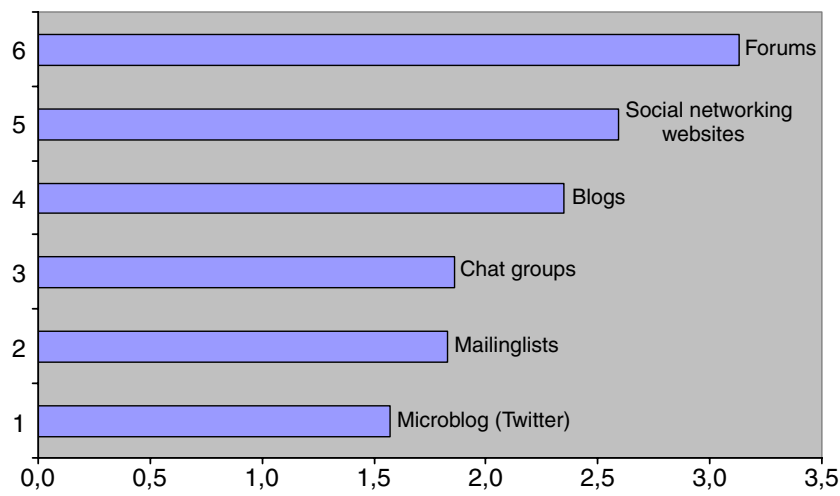

Fig. 2 Preferences regarding technologies used (x-as: $1=$ Uncomfortable, 2 = Pretty nice, $3=$ Nice, $4=$ Very nice) motives to obtain information and share experiences partly overlap. Among others respondents argued that they would like to learn more about their disease and how to deal with it, which means obtaining information and experiences from others. In addition, $13.1 \%$ described that they aimed to find recognition and understanding for being ill. This recognition could be obtained by other patients, rather than from professional healthcare providers or family members, because health companions know what it means to suffer from a specific disorder. Another important reason was to meet new people and come in contact with people in a similar situation (8.4\%). Also $5.8 \%$ of the respondents were just curious about these kinds of websites and what others described about their diseases. In addition, some reasons were mentioned less than five times, including among others: just for fun, the convenience of using this tool from home, to pass time, poor guidance and information of doctor, to be able to help others, possibility to express feelings and because a partner or family member was chronically ill. Respondents were also asked to what extent they agreed with several statements about motives behind on-line health companion contact use. The statement 'It is a way to gather information' was perceived the most important (mean score 4.32). This is comparable with the open-ended answers as just described, where obtaining information was mentioned most frequently. The second most important (4.21) motivation was the curiosity to what others think about something and the third one to help others (3.79). To pass time was considered as the least important. To increase understanding of the reasons for use, respondents indicated how often some factors gave rise to use on-line health companion contact: if they feel need to exchange information with others (mean score of 2.66 on a 4-point scale); if they heard new information concerning their disease (mean score of 2.65); if they were curious about other health companions or if they would like to share experiences with others (mean score of 2.64).

Manner of use Respondents were likely to use on-line health companion contact in combination with other healthcare services $(88.2 \%)$. Various types and combinations of health services were used. In general, respondents visited certain medical specialists, either in combination with other healthcare services or not. The majority (33.1\%) consulted multiple healthcare professionals including various medical specialists, therapists and GPs. Some of them also consult specialized nurses, therapies or home care. Next, $20.3 \%$ of the respondents only received care of medical specialists especially rheumatologists, cardiologists and pulmonary doctors. Multiple respondents $(16.9 \%)$ reported to visit medical specialists in combination with therapists for example physiotherapists. Another group (14.0\%) con- 
sulted medical specialists together with the GP. Some respondents $(7.0 \%)$ only visited a therapist or dietician and a $3.5 \%$ visited them along with the GP.

Effects of using on-line health companion contact Many respondents $(32.3 \%)$ did not report effects on their health because a chronic disorder could not be cured. However, seven respondents added that on-line contact could provide support or fun. An increased feeling of recognition was mentioned by $12.3 \%$ as a positive effect. Respondents feel assured by stories of users in similar situations; it provided support when reading experiences of patients with the same problems. Another effect included the increased understanding of a disease $(11.8 \%)$. Respondents had more knowledge about their disorder, treatment and how to deal with it. In addition, 5.6\% described that the most important effect was the obtained mental support. Users provide support and guidance to each other, for instance they feel less lonely. Other respondents $(5.1 \%)$ only mentioned to experience a positive effect on health, however they did not specify why. Better able to accept their disease was another positive effect indicated by $4.6 \%$. Next, the possibility to tell their story and express their feelings was experienced positively by $4.1 \%$. A few (3.1\%) described that they feel better because of increased social contact and the relaxing effect thereof. Furthermore, 2.6\% feel more self-confident due to using on-line health companion contact. An overview of the most frequently described effects on health is presented in Table 8 .

Besides the results of the open-ended question, closed responses were analyzed. Respondents appeared to mainly agree with the fact that they better understand their disease because of using on-line health companion contact. The second most important effect concerned the feeling to have

Table 8 Effects of using on-line health companion contact

\begin{tabular}{|c|c|c|}
\hline $\begin{array}{l}\text { Can you describe the effect(s) on } \\
\text { health because of using on-line } \\
\text { health companion contact? }\end{array}$ & $\begin{array}{l}\text { Number of similar } \\
\text { responses }(n=195)\end{array}$ & $\begin{array}{l}\text { Percentage } \\
(\%)\end{array}$ \\
\hline No effects on health & 63 & 32.3 \\
\hline $\begin{array}{l}\text { Increased recognition } \\
\text { (of others)/feeling reassured }\end{array}$ & 24 & 12.3 \\
\hline Increased understanding of disease & 23 & 11.8 \\
\hline Mental support & 11 & 5.6 \\
\hline Positive effect on health & 10 & 5.1 \\
\hline Better able to accept my disease & 9 & 4.6 \\
\hline $\begin{array}{l}\text { Feeling better because possibility } \\
\text { to express my feelings }\end{array}$ & 8 & 4.1 \\
\hline $\begin{array}{l}\text { Increased social contact/relaxing } \\
\text { effect }\end{array}$ & 6 & 3.1 \\
\hline $\begin{array}{l}\text { Increased involvement in decisions } \\
\text { concerning health }\end{array}$ & 6 & 3.1 \\
\hline $\begin{array}{l}\text { Increased feelings of } \\
\text { self-confidence }\end{array}$ & 5 & 2.6 \\
\hline
\end{tabular}

the right knowledge to be able to cope well with illness. Moreover, respondents agreed with the statement that they could better think along with their doctors about health. The statement that their health problems were reduced scored the lowest, which is comparable to the finding that most respondents described that no effects on health were experienced as seen in Table 9.

\section{Discussion and conclusion}

The motivations behind on-line health companion contact use and to what extent this tool can increase selfmanagement are affected by different factors. To start, predisposing factors play a role. The sociodemographics of the respondents can be described as follows: ages ranging from 19 to 69; they tend to be Dutch, women and married; they have a wide range of educational levels. Next, as could be expected, Internet usage at home also for non email related purposes is predictive of on-line health companion contact use. Respondents are likely to have the possibility to ask questions and discuss health problems with to close persons; therefore it is supposed that a poor social structure do not affect the choice to participate in on-line health companion contact. Surfing the Internet, in many cases for health related information, is the main source of becoming known with on-line health companion contact and specific websites providing this tool. Furthermore, Hyves pages and patient organizations appear to play a role in the introduction of these websites to patients.

The large amount of female respondents (85\%) compared to male is a remarkable finding. Several explanations for this result are suggested. Probably women make more use of on-line health companion contact; however, several other factors might have contributed to the high number of female respondents. For example, in general more women (30.8\%) compared to men $(24.3 \%)$ are suffering from chronic disorders [37]. Although, the diseases included in this study are not predominated by female patients, DBM and COPD are even more prevalent among men ([41, 42]). When comparing the findings of this study with another study conducted among users of on-line health companion tools, it appears that they also found high percentages of female users. Uden-Kraan found that $91 \%$ of the users of the on-line support groups under study were a woman. These results were expected because the illnesses included in this study, breast cancer, arthritis and fibromyalgia, especially occurred among female patients [29]. Furthermore, women are more likely to complete on-line questionnaires than men. It is suggested that they are more willing to participate or more interested in scientific research. No information about this thought is found in 
Table 9 Summary of user experience, motivation and effects drawn from the on-line questionnaire

\begin{tabular}{|c|c|c|c|}
\hline Variable/item & Response options & $\begin{array}{l}\text { Frequency } \\
(n=195)\end{array}$ & $\begin{array}{l}\text { Percentage } \\
(\%)\end{array}$ \\
\hline \multicolumn{4}{|l|}{ Perceived risks } \\
\hline That everyone had access to my data & Yes & 70 & 35.9 \\
\hline To receive incorrect information & Yes & 45 & 23.1 \\
\hline To become dependent on on-line contact & Yes & 10 & 5.1 \\
\hline \multicolumn{4}{|l|}{ Perceived need for on-line health companion contact } \\
\hline \multirow[t]{3}{*}{ What helped the most to deal with your health problems? } & Combination of both & 117 & 60.0 \\
\hline & Regular healthcare services & 72 & 36.9 \\
\hline & On-line health companion contact & 6 & 3.1 \\
\hline \multicolumn{4}{|l|}{ Obtained advice/referrals } \\
\hline \multirow[t]{4}{*}{ Receive advice concerning health and diseases? } & Rarely or never & 47 & 24.1 \\
\hline & Sometimes & 105 & 53.8 \\
\hline & Regular & 36 & 18.5 \\
\hline & Often & 7 & 3.6 \\
\hline \multirow[t]{4}{*}{ Recommended to professional healthcare providers? } & Rarely or never & 94 & 48.2 \\
\hline & Sometimes & 80 & 41.0 \\
\hline & Regular & 12 & 6.2 \\
\hline & Often & 9 & 4.6 \\
\hline \multirow[t]{5}{*}{ If yes, are following this advice? } & Rarely or never & 27 & 13.8 \\
\hline & Sometimes & 113 & 57.9 \\
\hline & Regular & 26 & 13.3 \\
\hline & Often & 5 & 2.6 \\
\hline & Not applicable & 24 & 12.3 \\
\hline \multicolumn{4}{|c|}{ Content of use (period; frequency; duration; technological preferences; type of user) } \\
\hline \multirow{5}{*}{$\begin{array}{l}\text { Since how long are you using on-line health } \\
\text { companion contact? }\end{array}$} & This is my first visit & 15 & 7.7 \\
\hline & Not longer than one month & 18 & 9.2 \\
\hline & Between a half and one year & 62 & 31.8 \\
\hline & Between one and two year & 37 & 19.0 \\
\hline & Longer than two years & 63 & 32.3 \\
\hline \multirow[t]{5}{*}{ Frequency of use } & Less than one time a month & 52 & 26.7 \\
\hline & More than one time a week, but less than one time a month & 22 & 11.3 \\
\hline & About one time a week & 33 & 16.9 \\
\hline & Multiple times a week & 65 & 33.3 \\
\hline & Multiple times a day & 23 & 11.8 \\
\hline \multirow[t]{4}{*}{ Duration of use } & Less than ten minutes & 71 & 36.4 \\
\hline & Ten to thirty minutes & 92 & 47.2 \\
\hline & Between a half and one hour & 26 & 13.3 \\
\hline & Longer than one hour & 6 & 3.1 \\
\hline \multirow[t]{2}{*}{ Type of access } & Closed & 110 & 56.4 \\
\hline & Open & 85 & 43.6 \\
\hline \multirow[t]{3}{*}{ Type of user } & Read messages and react on them & 112 & 57.4 \\
\hline & Only read messages of other users & 39 & 20.0 \\
\hline & Other... & 44 & 22.6 \\
\hline
\end{tabular}

literature. Another issue which can play a role is that women are more concerned with their disease. Overall, in the Netherlands men are working during the day and come home and would like to relax. On the other hand, women work for fewer hours and spent more time at home. Probably women have more time available and they start earlier thinking about their disease and feel need to use the Internet for searching information or contact. Regarding the time of completing the questionnaire, it appears that $55.4 \%$ of the women filled out the questionnaire during working hours (between 8.30 AM and 5.00 PM) compared to $44.8 \%$ of the men. 
Also the mean age of the respondents (44.3 years) is interesting to discuss which seems relatively young as most chronically ill are above 65 years of age as mentioned in paragraph 2.2. However, in the Netherlands, the mean age to develop COPD is 55 years or older; for DBM this is 63; CRD mainly occurred above 45 years of age; CHF mainly occurred above 65 years of age; asthma targets mainly children and youth; rheumatic disorders and chronic muscle disorders occur at all ages. The mean age of Dutch people in 2010 is 40.1 years [41]. The finding that a great part of the respondents has asthma or a rheumatic disorder, disorders that can occur at younger ages as just mentioned, can explain the relative young sample. Another effect which has to be considered is the assumption that younger persons are expected to make more use of Internet and computers compared to the older generation. However, as described before on-line applications are increasingly used among people above 45 years of age. Moreover elderly could prefer physical contact rather than on-line contact. With regard to these thoughts and findings, the mean age of the respondents seems to be an appropriate reflection.

In general, the respondents are satisfied with the healthcare services they received, among others because it is proper and effective. Multiple respondents value it important that healthcare professionals listen to their stories and take them seriously. Regarding the personal factors, the senses of selfefficacy of the respondents is high as they have confidence in their active involvement in decisions concerning health. Half of the respondents are able to take care of themselves and most of them prefer to have an equal partnership for the involvement in decisions about their healthcare.

Negative stories of other users are perceived as risks and barriers of on-line health companion contact by multiple respondents because they make them feel worse. Furthermore, perceived risks mainly include privacy concerns. Another barrier is the uncertainty if using this on-line tool is the right way to deal with health problems. According to the respondents, the most annoying disadvantages are the difficulty to estimate the quality of some messages, the possibility that typed messages can be interpreted wrongly and that questions are not always answered completely. As additional disadvantages again negative stories and whining of other users and privacy concerns are reported. On the other hand, advantages are perceived. Respondents agree the possibility to get into contact with others that find themselves in a similar situation quite easily as important. Moreover, the most frequently endorsed additional benefits are obtaining information or sharing experiences. Next, recognition and the easy use play a role. These benefits are considered as potential determinants of on-line health companion contact use.

The enabling factors explain on-line health companion contact use. Resources are generally characterized by low incomes compared to the general Dutch population and a high percentage of social benefits. Furthermore, most of the respondents are satisfied with the access to and availability of conventional healthcare services, therefore dissatisfaction with other healthcare services is not likely to play a great role in the decision to use on-line health companion contact. Also the background of people is not considered to be important since the respondents live across the Netherlands in agreement with the distribution of the general population per region.

The need for care factors play a role in on-line health companion contact. Respondents are mainly diagnosed with rheumatic disorders, asthma or COPD. However most respondents reported a fair health status, they indicated to be happy and some even very happy. The combination of different types of healthcare services and on-line health companion contact is seen as most helpful. Conventional health services are needed for the medical and theoretical part. On the other hand, on-line contact supports the mental part and practical part including experiences and advice.

The use patterns of the respondents vary a lot regarding the period, duration and frequency of use. In the selection of a specific website, different characteristics play a role: the topics discussed; the easy use for example Hyves; the access to the website, preferably closed; type of users for example concerning age; the organization of the website; the structure and lay out. Regarding the technology used, Hyves pages and forums providing a clear overview are experienced as attractive and accessible. Moreover, respondents can take different roles; the majority read messages and sometimes reacts on them. Others post messages, read messages and start discussions.

Different reasons for using on-line health companion contact are found. Based on the closed and open-ended responses, obtaining information is the most important motive; sharing experience with other users comes in second. Respondents would like to read stories, to learn more about their disease and how to deal with it. Furthermore, multiple respondents aim to find recognition and understanding for being ill. Another important reason is to meet new people and come in contact with people in a similar situation. Finally some respondents are just curious what others describe about their diseases.

The final study questions are how on-line health companion contact can improve outcomes of care and if it increases self-management. Almost one third of the respondents do not experience any effects on health. Others experience positive effects including an increased feeling of recognition, mental support and an increased amount of social support obtained from stories of other patients in similar situations. According to the OHCC Model, these effects contribute to an improved Quality of Life (QoL). Further, some respondents are better able to accept their 
disease. From the closed responses it appears that respondents mainly agree with the statements that they better understand their disease and that they had the feeling to have the right knowledge to be able to cope well with their illness because of using on-line health companion contact. Also respondents can better think along with their doctors about health. Regarding these findings and the OHCC Model, on-line health companion contact is suggested to increase the self-management of respondents because they feel better informed.

\subsection{Limitations to this study}

Some bias in the sampling procedure can be assumed because actively used websites are selected for involvement. Probably these websites are visited by more active users. However, regarding the results about the type of users this is not the case. Furthermore, we are dependent on the webmasters who had to react on our request and to provide permission. The main disadvantage of using an online questionnaire is that respondents drop out earlier compared to face to face situations [43]. To limit this drop out it is tried to keep it attractive for respondents to fill out the questionnaire. Despite having taken this into account, a considerable number of respondents only partially completed the on-line questionnaire. To examine whether there is selective attrition, those respondents who completed the questionnaire are compared with the respondents who partly complete it on crucial aspects, such as gender, motivation, perceived benefits and barriers, effects on health. This analysis showed hardly differences in the percentages women compared to men and the motivations perceived as important. After a few questions already a great part of the respondents stopped to fill out the questionnaire. Since the questions on effects of on-line health companion contact use are at the end of the questionnaire, no comparison could be made. Some viable reasons are assumed to play a role in the high number of respondents who leaved the questionnaire. Some users of on-line contact probably do not have the inclination to respond to questionnaires. Therefore, it can be expected that those persons more often decide not to complete it. This might especially be the case if a questionnaire is of considerable length, such as the one used in this study. In addition, it is not possible to check if respondents answered truthfully. However, no solution is available to prevent this problem; it is assumed that the chance for involvement of these kinds of persons is limited. Furthermore, one person can fill out multiple questionnaires. To prevent this, only one questionnaire per computer could be completed. Furthermore, the questionnaire was able to fill out for a limited time period because of the tight time schedule of this project. Finally, the findings of this study are difficult to generalize because of the relative small percentage of respondents with the same chronic disorders. Finally, it should be taken into account that the results included selfperceived outcomes. Respondents themselves estimated to what extent they profited from using on-line health companion contact. This does not prove that they truly profited from this participation. Although this study provides relevant insights into the characteristics of users, motivations and effects as experienced by the respondents, a randomized controlled trial or a longitudinal study is required to evaluate whether respondents are truly empowered.

\section{Recommendations}

For prospective research it would be useful to find different patterns of on-line health companion contact use between people with different types of diagnosis by performing a study among a wide variety of patients. When doing so it is important to include a relevant amount of patient for each type of disorder to say something and generalize the results. Furthermore, because this study suggests that on-line health companion contact empowers patients; it would be relevant to investigate this in more detail. A study focused on these effects will provide more insight in how on-line contact can further increase self-management. This information will provide useful recommendations for (Dutch) health policy as this aims to keep patients longer at home.

Almost all respondents have a Dutch nationality. However, no data is obtained regarding ethnicity referring to a group of people with a common culture and language. These characteristics would be relevant to measure in future research as they could play a role as well. Probably some cultures prefer the involvement of healthcare provider rather than taking information form the Internet for example. Therefore it is advised to conduct a similar type of research in other countries.

Regarding the experiences of respondents it is important for webmasters to keep overview and structure in the discussions conducted on websites. Furthermore, because negative stories and whining of other users are perceived as barriers, webmasters are advised to monitor discussion and intervene if necessary. To take privacy concerns into account, it is recommended to make websites only accessible for members for instance by a password. Other characteristics of websites important to consider for webmasters are the topics on which is focused. Seeing that online health companion contact is mainly used because of obtaining health information it will be important to focus on reliable information concerning a specific disease. Another aspect which webmasters can take into account is the age of users and technological characteristics. Also the size of the letters and pictures used on a website are useful to consider. 
For users it would be helpful if they are referred to certain websites on which they can expect reliable information. Maybe it is a good idea to develop a kind of quality hallmark. Especially guidance in wide range of online health companion contact is important for youth because it is important that they benefit from the on-line contact instead of confused or concerned. The promotion of on-line health companion contact among young people is also important because within several years these kinds of on-line application would be expected to be widely used for health related purposes.

Patient organizations play an important role in providing on-line health companion contact. Patients feel confident if websites are organized by these organizations. Patient organizations would be function as a platform. Therefore, it is recommended to pay more attention to on-line health companion contact because multiple patients are happy with this tool. Probably organizations could attend their members on the possibility to use this tool or provide for example a forum on their website where patients can share knowledge and experiences. The large number of female respondents indicates that men are less attracted to on-line contact. To reach more men with health problems and in need for information or contact it is recommended to promote on-line health companion contact among this group.

Also the development of on-line health companion specified to a certain category of age would be attractive for patients because some respondents mentioned that to find it important to discuss with people of similar ages. An example is the on-line youth community organized by the Reumapatiëntenbond which seemed successful based on the positive reactions of users. Such an on-line application for youth would be helpful for other patient organizations as well.

On-line health companion contact is seen as an important source of health information. This is an interesting trend as it can provide necessary information to patients concerning health and treatment. The question rise how this great need for health information can be explained. Is there a lack of health information provided by healthcare professionals and leaflets or is there just a lack of practical information? For health policy it would be useful to evaluate this so that they can react on this. Because respondents also agreed recognition and support as important, these websites are probably able to function as a coach for some patients. This would be helpful to keep patients longer at home. As this empowering of patients is aimed by Dutch health policy, it is important to monitor the information provided on these websites and to consider possible applications of these websites. In any case it is important to further develop websites providing on-line health companion contact because, based on the results if this study, they can be suggested to contribute to increased selfmanagement which is very important regarding the tensions on the Dutch healthcare system.
Acknowledgement We would like to thank all persons who enabled this research project. First of all, many thanks to all the webmasters and moderators, who gave permission to include their websites in this study. In particular, many thanks to all the respondents who were willing to fill out the on-line questionnaire and thereby helped to make this report possible.

Conflicts of interest None declared.

Open Access This article is distributed under the terms of the Creative Commons Attribution Noncommercial License which permits any noncommercial use, distribution, and reproduction in any medium, provided the original author(s) and source are credited.

\section{References}

1. Goris A, Mutsaers H. Ruimte voor arbeidsbesparende technologie om in 2025 voldoende zorg te bieden (Rapport): STG/Health Management Forum; 2008. (In Dutch)

2. Blokstra A, Baan CA, Boshuizen HC, Feenstra TL, Hoogenveen RT, Picavet HSJ, Smit HA, Wijga AH, Verschuren WMM. Vergrijzing en toekomstige ziektelast. Prognose chronische ziektenprevalentie 2005-25. (Impact of the ageing population on burden of disease. Projections of chronic disease prevalence for 2005-2025). RIVM report 260401004. 2007; (In Dutch)

3. Fleming KC, Evans JM, Chutka DS. Caregivers and clinician shortages in an aging nation. Mayo Clin Proc. 2003;78(8):1026-40.

4. VWS. Maatschappelijke opgaven volksgezondheid en gezondheidszorg. Update anno 2009 met prioritaire thema's voor de kennis- en innovatie-agenda voor de gezondheidssector. Den Haag: MinVWS; 2009. In Dutch.

5. Blanson Henkemans OA, Alpay LL, Dumay ACM. Aging in place. Self-care in smart home environments. In: Al-Qutayri MA, Smart home systems. Olajnica: In-Tech. 2010a;105-120.

6. Chinman M, Kloos B, Oçonnell M, Davidson L. Service providers' views of psychiatric mutual support groups (electronic version). J Community Psychol. 2002;30:349-66.

7. van den Borne HW, Pruyn JFA, van den Heuvel WJA. Effects of contacts between cancer patients. Patient Educ Couns. 1987;9:3351.

8. Kleinman SS. Membership has its benefits: computer-mediated communication and social identification in an on-line discussion group for women in science and engineering. Dissertation Abstr Int. 1998;59(4A):0996.

9. Lazar J, Buckwater J, Hanst E, Preece J. Collecting user requirements in a virtual population: A case study. 2001. Manuscript submitted for publication.

10. Miller JK, Gergen KJ. Life on the line: the therapeutic potentials of computer-mediated conversation. J Marital Fam Ther. 1998;24 (2):189-202.

11. Prins JB. Medisch en psychologisch, meer dan logisch! Inaugural address, April 16, 2010. Nijmegen: Radboud University; 2010. In Dutch.

12. Spiegel D. Mind matters - group therapy and survival in breast cancer. N Engl J Med. 2001;345(24):1767-8.

13. Penson RT, Benson RC, Parles K, Chabner BA, Lynch Jr TJ. Virtual connections: internet healthcare. Oncologist. 2002;7(6):555-68.

14. Pector EA. Internet health support groups: their uses, formats, benefits, risks, facilitation, and research approaches. Mednet. 2003.

15. Ziebland S, Chappie A, Dumelow C, Evans J, Prinjha S, Rozmovitis L. How the internet affects patients' experience of cancer: a qualitative study. Br Med J. 2004;328:564.

16. Beck CT. Benefits of participating in Internet interviews: women helping women. Qual Health Res. 2005;15(3):411-22. 
17. Keijser WA. On-line gezondheidsinformatie en lotgenotencontact. E-Health series Deel 1. Utrecht: Wacomed; 2005.

18. de Bruin J, Ventevogel A. Patiëntencommunities op het Web. Theorie en praktijk. Amsterdam: VU uitgeverij; 2007. In Dutch.

19. Tanis M. Health-Related on-line forums: what's the big attraction. J Health Commun. 2008;13(5):5-23.

20. Albrecht TL, Goldsmith D. Social support, social networks, and health. In: Thompson TL, Dorsey AM, Miller KI, Parrot R, editors. Handbook of health communication: 263-84. Mahwah: Lawrence Erlbaum Associates, Inc.; 2003.

21. Cummings JN, Kiesler SB, Sproull L. Beyond hearing: where a real-work and on-line support meet. Group Dynamics. Theory research Pract. 2002;6(1):78-88.

22. Bass SB, Ruzek SB, Gordon TF, Fleisher L, McKeown-Conn N, Moore D. Relationship of Internet health information use with patient behavior and self-efficacy: experiences of newly diagnosed cancer patients who contact the National Cancer Institute's Cancer Information Service. J Health Commun. 2006;11:219-36.

23. Murray E, Lo B, Pollack L, Donelan K, Catania J, Lee K, et al. The impact of health information on the Internet on healthcare and the physician-patient relationship: national U.S. survey among 1.050 U.S. physicians. J Med Internet Res. 2003;5:e17.

24. Ferguson T. Patient, heal thyself: health in the information age. Futurist. 1992;26:9-14.

25. Hoch D, Ferguson T. What I've learned from E-Patients. PLoS Med. 2005;2(8):e206.

26. Demiris G. The diffusion of virtual communities in healthcare: concepts and challenges. Patient Educ Couns. 2006;62:178-88.

27. Winkelman WJ, Choo CW. Provider-sponsored virtual communities for chronic patients: improving health outcomes through organizational patient-centered knowledge management. Health Expect. 2003;6:352-8.

28. van Uden-Kraan CF, Drossaert CHC, Taal E, Shaw BR, Seydel ER, Van de Laar MAFJ. Empowering processes and outcomes of participation in on-line support groups for patients with breast cancer, arthritis, or fibromyalgia. Qual Health Res. 2008;18(3):405-17.

29. van Uden-Kraan CF. On-line peer support for patients with somatic diseases. UT Universiteit Twente (224 pag.) (Enschede: Universiteit Twente). Prom./coprom.: Prof.dr. MAFJ van de Laar, Prof.dr. ER Seydel \& Dr. CHC Drossaert; 2008a.
30. Wright K. Social support within an on-line cancer community: an assessment of emotional support, perceptions of advantages and disadvantages, and motives for using the community from a communication perspective. J Appl Commun Res. 2002;30:195209.

31. Cotten SR, Gupta SS. Characteristics of on-line and offline health information seekers and factors that discriminate between them. Soc Sci Med. 2004;59(9):1795-806.

32. van Uden-Kraan CF, Drossaert CHC, Taal E, Smit WM, Siesling S, Bernelot Moens HJ, et al. Health-related Internet use by patients with somatic diseases: frequency of use and characteristics of users. Inform Health Soc Care. 2009;34 (1):18-29.

33. Vos FSM, Cremer R. (2008) De 'ervaren generatie' in beeld gebracht. TNO-rapport. R08961/031-20034.

34. 50+Expertisecentrum [on-line]. Accessed on: 16-02-2010. Available from: http://www.50plusexpertisecentrum.nl. (In Dutch). 2010.

35. Finfgeld DL. Therapeutic groups on-line: the good, the bad and the unknown. Issues Ment Health Nurs. 2000;21(3):241-56.

36. Kittur A, Chi E, Pendleton BA, Suh B, Mytkowicz T. Power of the Few vs. Wisdom of the Crowd: Wikipedia and the Rise of the Bourgeoisie Export. World Wide Web; 2007. 1(2).

37. RIVM [on-line]. Accessed on: 16-03-2010. Available from: http:// www.rivm.nl/gezondheid/chronische/. 2010.

38. Tijssen ECG. On-line health companion contact for people with chronic diseases: Inventory study about this tool and on-line questionnaire among users. Internship report; 2010.

39. CPB[on-line]. Accessed on: 12-03-2010. Available from: www. cpb.nl; 2010.

40. UWV [on-line]. Accessed on: 12-04-2010. Available from: http:// www.uwv.nl/index.aspx. 2010.

41. CBS Statline. Accessed on: 12-03-2010. Available from: http:// statline.cbs.nl/statweb/; 2010.

42. Boezen HM, Smit HA, Postma DS. Astma samengevat. In: Volksgezondheid Toekomst Verkenning, Nationaal Kompas Volksgezondheid, versie 3.21. Bilthoven: RIVM; 2010. (In Dutch)

43. Blanson Henkemans O, Rogers W, Dumay ACM. Personal characteristics and the law of attrition in randomized controlled trials of eHealth for self management. 2010b; Submitted. 